\title{
Performance of a UASB Effluent Treatment Plant Treating Malt Ingredient Manufacturing Wastewater
}

\author{
Ryland Cairns (Corresponding author) \\ Fontus Environmental, Thirsk, North Yorkshire, England \\ Email: Ryland@fontusenvironmental.com
}

Paul Mead

Muntons, Cedar Maltings, Stowmarket, Suffolk, IP14 2AG, United Kingdom

Received: May 30, 2017 Accepted: June 23, 2017

doi:10.5296/emsd.v6i2.11314 URL: https://doi.org/10.5296/emsd.v6i2.11314

\begin{abstract}
Anaerobic Digestion has gained popularity in recent years due to its significant contribution towards achieving waste management and renewable energy targets. One particular technology that has been widely used in the treatment of high strength organic wastewaters across a wide range of industries is upflow anaerobic sludge blankets (UASBs). A malt ingredients manufacturing factory has successfully applied this technology as a cost effective way to treat their high strength effluent, however unlike other industries there is a lack of research regarding the wastewater characterisation or UASB performance at either lab or full scale. This paper aims to address this gap in knowledge and provide information on both the wastewater composition and on the ability of a full-scale mesophilic UASB to treat it over a period of 638 days. Analysis of the wastewater revealed that the manufacture of malt ingredients produces a high strength effluent, which fits within the realms of previously documented wastewaters despite not sharing a similar characterisation profile. Mesophilic UASB has been show to be an effective and robust technology option for the treatment of this type of wastewater displaying steady operational performance even when conditions were in excess of the design limit. Due to the robust operational performance of the plant the main factor limiting total methane production was shown to be the organic loading rate.
\end{abstract}

Keywords: Anaerobic Digestion, UASB, Malt, Wastewater, Trade effluent

\section{Introduction}

Anaerobic digestion (AD) is considered a mature technology in Europe for the treatment of 
organic waste and generation of green energy (Da Baere and Mattheeuws, 2012; Surendra et al., 2013; Micolucci et al., 2015). In recent years it has gained popularity both in its application (ADBA, 2016) and as a topic of research (Carrere et al., 2015) due to its significant contribution towards achieving waste management targets, renewable energy goals (Bekkering et al., 2016) and enhancing the value of organic residues (Chen et al., 2008). Rizvi et al. (2013) goes on to summarise other benefits including low construction costs, low operational footprint, low sludge production, energy generation in the form of biogas as well as relatively simple operation and maintenance requirements (Singh et al., 2013); whilst being robust in terms of Chemical Oxygen Demand (COD) removal efficiencies (Conceição et al., 2013), pH stability and recovery time (Hernández and Rodríguez, 2013).

There are a number of anaerobic treatments including anaerobic lagoons, fixed bed reactors, fluidised beds and anaerobic membrane bioreactors (Satyawali and Balakrishnan, 2008) however one of the most widely used anaerobic techniques used for the treatment of high strength organic effluents is the upflow anaerobic sludge blanket (UASB) (Musee et al., 2016). It has been successfully applied in treating a number of industrial effluents including: Palm oil mill effluent (Lee, 2006); Paper mill wastewater (Kamali et al., 2016); Distillery wastewater (Musee et al., 2016); dairy wastewater (Tawfik et al., 2008); fishery wastewater (Huang et al., 2009); slaughterhouse wastewater (Chavez et al., 2005); Piggery effluent (Huang et al., 2005) and municipal wastewater (Rivzi et al., 2015). The UASB is deemed to be particularly reliable reactor performance regularly achieving COD removal efficiencies in excess of $80 \%$ and biogas $\mathrm{CH}_{4}$ concentration in excess of $50 \%$ for a range of wastewaters and reactor specifications (Latif et al., 2011). This reliability is maintained through the control of key process parameters including operating temperature, $\mathrm{pH}$, alkalinity, macronutrients $(\mathrm{N}, \mathrm{P}$, $\mathrm{SO}_{4}{ }^{-2}$ ), micronutrients (trace metals) Organic Loading Rate (OLR), Hydraulic Retention Time (HRT) and Upflow Velocity $\left(\mathrm{V}_{\mathrm{up}}\right)$ which all have an impact on chemical and biological reaction rates (Latif et al., 2011; Moraes et al., 2015).

One industry which also produces high strength organic wastewater is the malt ingredients (MI) manufacturing industry which processes malted barley in to malt extract. It has been reported that a UASB reactor has been successfully used for the treatment of this wastewater and resulted in a number of benefits relating to waste treatment, energy savings and resource recovery (Koller, 2016). Despite the apparent suitability of this technology for the treatment of MI wastewater there remains a lack of available literature both on the characterisation of this wastewater and of the performance of UASB for treating this effluent stream.

The present study investigates the performance of the UASB at the site mentioned in Koller (2016). UASB performance in terms of COD removal, biogas yield and methane concentration will be investigated as well as the impact that the key process parameters of HRT, OLR and temperature have on these. The study will also provide a basic characterisation of wastewater produced by the MI process. 


\section{Materials and Methods}

\subsection{Plant Layout}

The UASB plant in this study is based at Muntons Malt Ingredients Factory in Stowmarket, UK. The feed for the reactor is generated by the operation and washdown of a variety of process equipment (evaporator, band drier, spray drier, ultrafilter and canning) the use of which is dictated by production requirements. As such the volume, temperature and concentration of the wastewater is variable in nature despite the fact that all the organic material originates from malt. The process flow for the AD plant is shown in Figure 1 whilst design parameters are detailed in Table 1.

Table 1. Process Design

\begin{tabular}{|l|l|}
\hline Parameter & Design Value \\
\hline Flow $\left(\mathrm{m}^{3} / \mathrm{d}\right)$ & $200(280 \mathrm{max})$ \\
\hline COD $(\mathrm{mg} / \mathrm{L})$ & 40,000 \\
\hline Hydraulic Retention Time $($ day $)$ & $10(7 \mathrm{~min})$ \\
\hline Organic Loading Rate $(\mathrm{Kg}$ COD/m $/$ /day) & $4(5.6$ max $)$ \\
\hline Organic Nitrogen $(\mathrm{TKN})(\mathrm{mg} / \mathrm{L})$ & 110 \\
\hline Ammonia $(\mathrm{mg} / \mathrm{L})$ & 16 \\
\hline Phosphorus $(\mathrm{mg} / \mathrm{L})$ & 230 \\
\hline Total Suspended Solids $(\mathrm{TSS})(\mathrm{mg} / \mathrm{L})$ & 2,000 \\
\hline Sulphate $(\mathrm{mg} / \mathrm{L})$ & 380 \\
\hline
\end{tabular}

Raw wastewater is pumped from the MI factory and through a $1 \mathrm{~mm}$ drum screen to remove coarse solids prior to it being stored in a $650 \mathrm{~m}^{3}$ buffer tank to aid with flow balancing. From the buffer tank the wastewater enters a conditioning tank $\left(64 \mathrm{~m}^{3}\right)$ where the $\mathrm{pH}$ and temperature is regulated. Sodium Hydroxide solution $(\mathrm{NaOH} 32 \%)$ can be dosed to correct $\mathrm{pH}$ if required, with the dose rate being set manually via the operators to achieve a suitable $\mathrm{pH}$. Since start up Sodium Hydroxide dosing has not been required. As $60^{\circ} \mathrm{C}$ to $80^{\circ} \mathrm{C}$ water is used in the MI factory effluent temperature is corrected via a chiller unit which is automatically controlled to ensure the conditioned wastewater is at a suitable temperature $\left(35^{\circ} \mathrm{C}-38^{\circ} \mathrm{C}\right)$ for mesophilic anaerobic digestion. The incoming wastewater is pumped in to the $2047 \mathrm{~m}^{3}$ Enprotech UASB where it percolates up through the granular biomass sludge blanket. The biomass used to seed this plant came from a mesophilic UASB reactor treating dairy wastewater. A homogenous blend inside the reactor is achieved by hydraulic mixing. Following treatment the wastewater, biomass and biogas is separated at the top of the reactor via a three phase separator. The treated effluent goes on for further treatment via conventional aerobic treatment (activated sludge) prior to it being discharged under an Environmental Permit to a local watercourse. The close proximity of the activated sludge plant means that off-gas from the reactor can be treated aerobically by feeding it through the activated sludge reactor. The separated biomass is retained within the reactor and settles out in the sludge blanket. The biogas from the reactor is stored in a $400 \mathrm{~m}^{3}$ biodome prior to it being passed through to a Combined Heat and Power unit with a $499 \mathrm{~kW}$ MAN engine maintained by EnerG. 


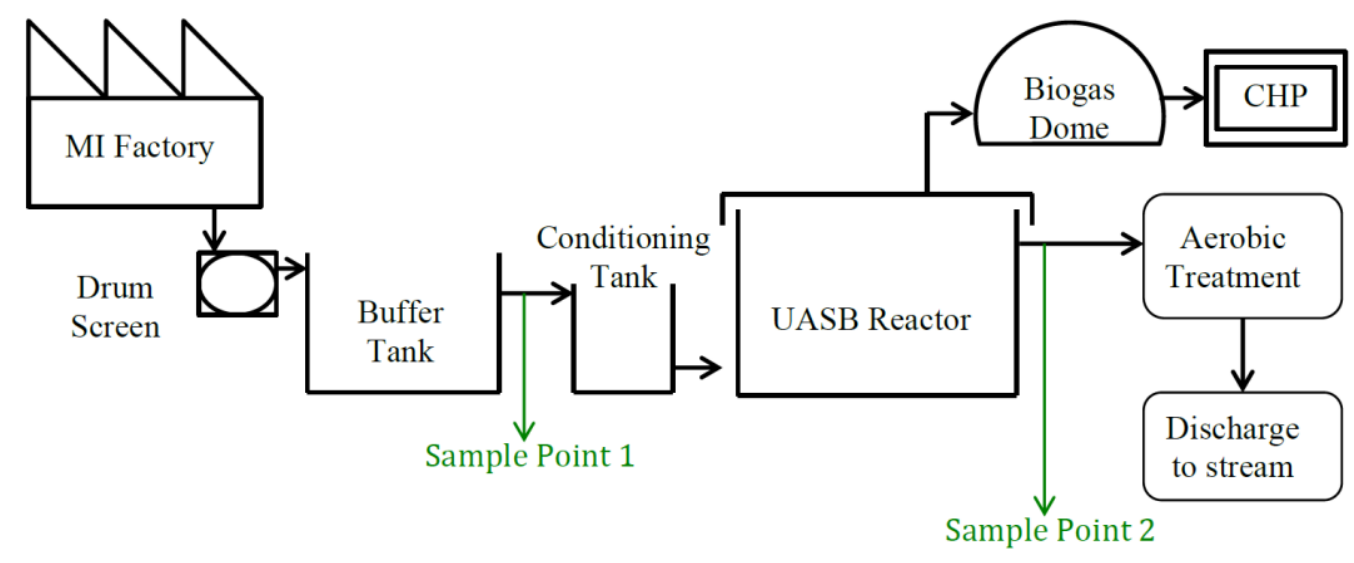

Figure 1. Basic layout of the Muntons AD plant

\subsection{Characterization of MI Wastewater and Treated Wastewater}

Due to a number of processes within the MI factory (band drier, spray drier, ultra-filtration, canning operations) the characteristics of the individual wastewaters can differ considerably, as such daily samples of the blended untreated wastewater were collected from the outlet of the buffer tank prior to it entering the AD plant (Figure 1; Sample Point 1). A daily sample of the treated wastewater was taken directly after the UASB reactor (Figure 1; Sample Point 2) to give an indication of plant performance and was conducted over a period of 638 days between 01/08/2015 and 30/04/2017.

Physiochemical analysis of the wastewater and treated wastewater was conducted in the in-house laboratory and included Chemical Oxygen Demand, total Kjeldahl Nitrogen, Ammonia, Total Phosphorus, Total Suspended Solids (TSS), pH and sulphate. Parameters were measured in accordance with the standard methods for the examination of water and wastewater (American Public Health Association, 2012).

Standard Methods (4500-SO $\left.{ }_{4}{ }^{2-} \mathrm{D}\right),\left(4500 \mathrm{C}-\mathrm{N}_{\text {org }} \mathrm{C}\right)$ and $\left(4500-\mathrm{NH}_{3} \mathrm{C}\right)$ were utilized to determine Sulfate, Organic Nitrogen and total phosphorus concentrations respectively. Whilst $\left(4500-\mathrm{H}^{+} \mathrm{B}\right),(5220 \mathrm{D})$ and $(4500-\mathrm{P} \mathrm{C})$ were used to determine $\mathrm{pH}, \mathrm{COD}$ and total phosphorus.

\section{Results and Discussion}

\subsection{Characterization of Wastewater}

In Tables 2 and 3 the composition of the raw and treated wastewater is displayed respectively. This includes the minimum and maximum values recorded over the sampling period as well as the means and associated standard deviation.

\subsubsection{Untreated MI Wastewater}

Influent COD concentration ranged from $15,422 \mathrm{mg} / \mathrm{L}$ to $49,420 \mathrm{mg} / \mathrm{L}(33,998 \mathrm{mg} / \mathrm{L}$ difference) with a mean of $29,009 \mathrm{mg} / \mathrm{L}(\mathrm{STD} \pm 5,939)$. A similarly large range of was apparent for organic nitrogen levels $(186 \mathrm{mg} / \mathrm{L}$ to $797 \mathrm{mg} / \mathrm{L}$ with a mean of $372 \mathrm{mg} / \mathrm{L})$ and phosphorus 
$(3.57 \mathrm{mg} / \mathrm{L}$ to $212.00 \mathrm{mg} / \mathrm{L}$ with a mean of $123.89 \mathrm{mg} / \mathrm{L})$. This leads to this a mean CNP ratio of roughly 234:3:1.

Ammonia and Sulphate were both relatively low compared to COD. Ammonia was monitored as having a range of $1.72 \mathrm{mg} / \mathrm{L}$ to $73.80 \mathrm{mg} / \mathrm{L}$ with a mean of $8.42 \mathrm{mg} / \mathrm{L}(\mathrm{STD} \pm 9.47)$ which gives a mean COD:NH3 ratio of 3445:1, whilst Sulphate had a range of $140 \mathrm{mg} / \mathrm{L}$ to $2384 \mathrm{mg} / \mathrm{L}$ with a mean of $666.11 \mathrm{mg} / \mathrm{L}(\mathrm{STD} \pm 145.33)$ which gives a mean COD:SO 4 ratio of 44:1. Considering the relative high COD concentrations neither the ammonia and sulphate should not inhibit the anaerobic processes.

$\mathrm{pH}$ was generally acidic in nature with a mean of $4.05(\mathrm{STD} \pm 1.14)$ however this did range from 3.08 to 11.64 . The $\mathrm{pH}$ was recorded as being in excess of 7.00 for 25 days $(3.91 \%$ of sampling period) and was a result of a high volume of caustic cleans occurring within the factory.

Table 2. Untreated MI Wastewater Composition

\begin{tabular}{|l|l|l|}
\hline Parameter & Range & Mean \\
\hline Chemical Oxygen Demand (COD) (mg/L) & $15,422-49,420$ & $29,009 \pm 5,939$ \\
\hline Organic Nitrogen (TKN) (mg/L) & $186-797$ & $372 \pm 166$ \\
\hline Ammonia (mg/L) & $1.72-73.80$ & $8.42 \pm 9.47$ \\
\hline Phosphorus (mg/L) & $3.58-212.00$ & $123.89 \pm 38.69$ \\
\hline Total Suspended Solids (TSS) (mg/L) & $1,280-9,828$ & $3,059 \pm 1,058$ \\
\hline pH & $3.08-11.64$ & $4.05 \pm 1.14$ \\
\hline Sulphate (mg/L) & $140-2,384$ & $666.11 \pm 145.33$ \\
\hline
\end{tabular}

The values for the various parameters found in Table 2 are comparable to those observed in other UASBs treating different effluent types however there were no similar characterization profiles even amongst other industries involved in the processing of grains (Erashin et al., 2011; Rajeshwari et al., 2000 and Latif et al., 2011). From a macronutrient perspective it has been highlighted that for optimum $\mathrm{CH}_{4}$ yield a CNP ratio of 100:3:1 is desired. For the current wastewater a CNP of 234:3:1 is apparent, this high C to NP ratio could lead to a deficiency process with poor buffering capacity (Rajeshwari et al., 2000) and as such pH should be monitored closely. Benefits could be obtained from characterization of further MI wastewaters from different factories as well as from individual processing equipment. Future studies should include micronutrients analysis due the to influence they exert on long term operating performance (Facchin et al., 2013).

\subsubsection{Treated Wastewater}

Over the 638 day sampling period the treated effluent had a COD concentration ranging from $1,630 \mathrm{mg} / \mathrm{L}$ to $6,516 \mathrm{mg} / \mathrm{L}$ (a difference of $4886 \mathrm{mg} / \mathrm{L}$ ) with a mean of $4,244 \mathrm{mg} / \mathrm{L}$ (STD \pm 758 ). Total organic nitrogen levels ranged from $42 \mathrm{mg} / \mathrm{L}$ to $417 \mathrm{mg} / \mathrm{L}$ with a mean of $193.09 \mathrm{mg} / \mathrm{L}$ (STD \pm 63.02 ) and total phosphorus levels ranged from $28.2 \mathrm{mg} / \mathrm{L}$ to $175.00 \mathrm{mg} / \mathrm{L}$ with a mean of $193 \mathrm{mg} / \mathrm{L}$ (STD63.02). This leads to a mean CNP ratio of roughly 100:4:2 which makes it much more ideal for the subsequent aerobic treatment where a CNP ratio of 100:5:1 is desired (Ammary, 2004) and thus reduces the need for excessive chemical treatment. 
Sulphate continued to be relatively low compared to COD. Sulphate was monitored as having a range of $142 \mathrm{mg} / \mathrm{L}$ to $781 \mathrm{mg} / \mathrm{L}$ with a mean of $497.91 \mathrm{mg} / \mathrm{L}(\mathrm{STD} \pm 113.01)$ which gives a mean COD: $\mathrm{SO}_{4}$ ratio of 8.5:1.

Table 3. Treated Wastewater Composition

\begin{tabular}{|l|l|l|}
\hline Parameter & Range & Mean \\
\hline Chemical Oxygen Demand (COD) (mg/L) & $1,630-6,516$ & $4,244 \pm 758$ \\
\hline Organic Nitrogen (TKN) (mg/L) & $42-417$ & $193.09 \pm 63.02$ \\
\hline Phosphorus (mg/L) & $28.2-175.0$ & $93.96 \pm 30.29$ \\
\hline Total Suspended Solids (TSS) (mg/L) & $592-4830$ & $2546.27 \pm 628.36$ \\
\hline Sulphate (mg/L) & $142-781$ & $497.91 \pm 113.01$ \\
\hline
\end{tabular}

\subsection{Process Parameters}

In Table 4 the values of the key process parameters associated with successful UASB are presented, these can be compared against the plant design parameters in Table 1 .

Despite the inclusion of a buffer tank the plant experiences a relatively high range of flows from a low of $46 \mathrm{~m}^{3} / \mathrm{d}$ to a high of $326 \mathrm{~m}^{3} / \mathrm{d}$ with a mean of $210 \mathrm{~m}^{3} / \mathrm{d}(\mathrm{STD} \pm 41)$. This is a result of natural variations within the manufacturing process where production volumes and variety can influence both the flow and strength of the wastewater. Parameters influenced by flow such as the HRT and $\mathrm{V}_{\text {up }}$ (associated with reactor volume and surface area respectively) also experience a relatively high range of conditions. For the most part these conditions are outside the plant design flow of $200 \mathrm{~m}^{3} / \mathrm{d}$ but within the maximum design limit of $280 \mathrm{~m}^{3} / \mathrm{d}$ on all but 31 days.

The Organic Loading Rate (OLR) is influenced by both incoming flow and COD concentration of the MI wastewater in relation to the volume of the reactor. During operations the OLR ranged from $0.82 \mathrm{Kg} \mathrm{COD} / \mathrm{m}^{3} /$ day to $5.68 \mathrm{Kg} \mathrm{COD} / \mathrm{m}^{3} /$ day with a mean of $3.06 \mathrm{Kg}$ $\mathrm{COD} / \mathrm{m}^{3} /$ day $(\mathrm{STD} \pm 0.78$ ). Typically the plant operates below the designed OLR of $4 \mathrm{Kg}$ $\mathrm{COD} / \mathrm{m}^{3} /$ day however on occasions this is pushed towards the design limit $(5.60 \mathrm{Kg}$ $\mathrm{COD} / \mathrm{m}^{3} /$ day) and on one occasion over this. This is a result of days when the flow (31 days) or concentration (16 day) of the waste water is in excess of the design max.

For a mesophilic UASB the plant requires a temperature of $35^{\circ} \mathrm{C}$ to $37^{\circ} \mathrm{C}$ to perform optimally (Bolzonella et al., 2012). The temperature within the reactor ranged from $33^{\circ} \mathrm{C}$ to $41^{\circ} \mathrm{C}$ with a mean of $37^{\circ} \mathrm{C}(\mathrm{STD} \pm 2.0)$. It is recognised that the temperature within the reactor was in excess of the desired optimum operational range on a number of occasions, the longest of which saw temperatures in excess of $39^{\circ} \mathrm{C}$ for up to 30 consecutive days. This is still within a suitable range $\left(20^{\circ} \mathrm{C}\right.$ to $\left.42^{\circ} \mathrm{C}\right)$ for mesophilic digestion.

Despite a wide range of $\mathrm{pH}$ associated with the incoming effluent ( $\mathrm{pH}$ of $3.08-11.64)$ the treated effluent leaving the plant maintains a steady $\mathrm{pH}$ which ranging from 7.00 to 7.90 with a mean of $7.45( \pm 0.19)$. Considering the potential for poor buffering capacity due to the high C to NP concentration (Rajeshwari et al., 2000) and no extra alkalinity addition in the form of $\mathrm{NaOH}$ or lime solution this is particularly interesting. Future plant studies should include the 
investigation of alkalinity levels within the plant, especially considering it is a key operation parameter (Latif et al., 2011; Moraes et al., 2015).

The concentration of total Volatile Fatty Acids (VFAs) was recorded to range from $228 \mathrm{mg} / \mathrm{L}$ - $1828 \mathrm{mg} / \mathrm{L}$ with a mean of $460 \mathrm{mg} / \mathrm{L}$ and a standard deviation of $\pm 167 \mathrm{mg} / \mathrm{L}$.

Table 4. Process Parameters

\begin{tabular}{|l|l|l|}
\hline Parameter & Range & Mean \\
\hline Flow $\mathrm{m}^{3} / \mathrm{d}$ & $46-326$ & $210 \pm 41$ \\
\hline Hydraulic Retention Time (HRT) (days) & $6.07-43.04$ & $9.91 \pm 2.87$ \\
\hline $\mathrm{V}_{\text {up }}(\mathrm{m} / \mathrm{s})$ & $0.01-0.06$ & $0.04 \pm 0.01$ \\
\hline Organic Loading Rate (OLR) $\left(\mathrm{Kg} \mathrm{COD} / \mathrm{m}^{3} /\right.$ day) & $0.8-5.68$ & $3.06 \pm 0.78$ \\
\hline Temperature $\left({ }^{\circ} \mathrm{C}\right)$ & $33-41$ & $37 \pm 2$ \\
\hline $\mathrm{pH}$ & $7.00-7.90$ & $7.45 \pm 0.19$ \\
\hline Volatile Fatty Acids $(\mathrm{mg} / \mathrm{l})$ & $228-1828$ & $460 \pm 167$ \\
\hline
\end{tabular}

\subsection{Process Performance}

Reactor performance parameters and their respective values are summarized in table 5. The impact of key process parameters on UASB performance are examined further in Figures 2 to 6. Despite the variable nature of flows, organic loading, temperature and biogas production the mean COD removal performance, biogas methane concentration and Biological Methane Potential (BMP) all remained relatively steady with respective means of $84.94 \%$ (STD \pm 3.32 ), $58.08 \%$ (STD \pm 2.96 ) and $0.27 \mathrm{mgCH}_{4} / \mathrm{mgCOD} /$ day (STD \pm 0.05 ). In contrast daily biogas production had a relatively wide range $\left(439 \mathrm{Nm}^{3} / \mathrm{d}\right.$ to $\left.5992 \mathrm{Nm}^{3} / \mathrm{d}\right)$ with a mean of 3472.14 $\mathrm{Nm}^{3} / \mathrm{d}(\mathrm{STD} \pm 939.52)$. The concentration of Hydrogen Sulphide in the biogas was recognised as particularly high at $715.31 \mathrm{mg} / \mathrm{L}(\mathrm{STD} \pm 204.99)$ with a range of $39 \mathrm{mg} / \mathrm{L}-1339 \mathrm{mg} / \mathrm{L}$ although routine CHP maintenance has yet to pick up any evidence for corrosion inside the engine.

Table 5. Process Performance

\begin{tabular}{|l|l|l|}
\hline Parameter & Range & Mean \\
\hline COD Removal $(\%)$ & $73.16-94.80$ & $84.94 \pm 3.32$ \\
\hline Biogas Produced $\left(\mathrm{Nm}^{3} / \mathrm{d}\right)$ & $439-5992$ & $3472.14 \pm 939.52$ \\
\hline Methane Concentration $(\%)$ & $43.70-69.10$ & $58.08 \pm 2.96$ \\
\hline Methane Produced $(\mathrm{Kg} / \mathrm{d})$ & $206-2362$ & $1365 \pm 358$ \\
\hline BMP $\left(\mathrm{mgCH}_{4} / \mathrm{mgCOD} /\right.$ day $)$ & $0.14-0.59$ & $0.27 \pm 0.05$ \\
\hline Hydrogen Sulphide $(\mathrm{mg} / \mathrm{L})$ & $39-1339$ & $715.31 \pm 204.99$ \\
\hline
\end{tabular}

\subsubsection{The Impact of Temperature on Performance}

The results presented in Figure 2 show that operating temperature has minimal impact to plant performance in terms of COD removal efficiency $( \pm 2 \%)$ and methane concentration of the biogas $( \pm 4 \%)$. This could be expected as mesophilic reactors are recognised as having greater process stability with regards to temperature variations when compared to 


\section{Ml Macrothink}

thermophilic reactors ( $\mathrm{Yu}$ et al, 2002), this robustness contributes towards the operator preference towards mesophilic systems (Latif et al., 2011). Trend lines reveal that COD removal efficiency was greatest between $36^{\circ} \mathrm{C}$ to $38^{\circ} \mathrm{C}$ at $85 \%\left(\mathrm{R}^{2}=0.01\right)$ whilst percentage methane concentration lowest between $37^{\circ} \mathrm{C}$ to $39^{\circ} \mathrm{C}$ at $57 \%\left(\mathrm{R}^{2}=0.05\right)$. For COD removal this is similar to the optimal range of $35^{\circ} \mathrm{C}$ to $37^{\circ} \mathrm{C}$ found in other studies (Bolzonella et al., 2012) with a drop off in bacterial activity seen below $35^{\circ} \mathrm{C}$ (Rajeshwari et al., 2000).

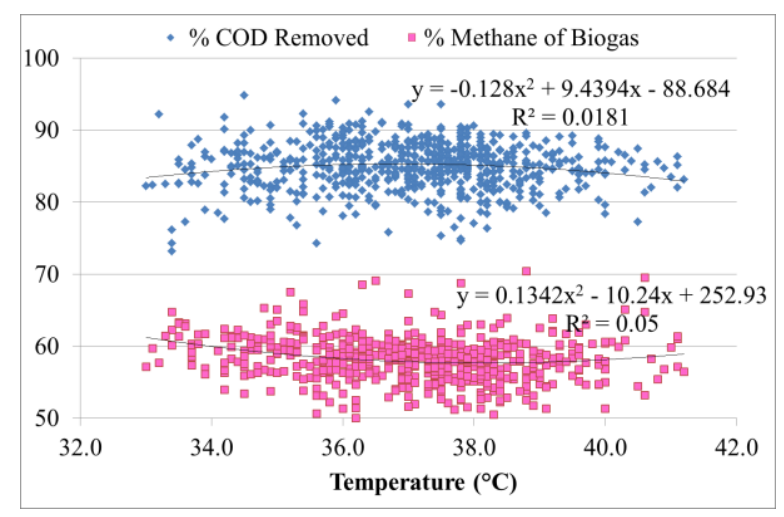

Figure 2. The impact of temperature on AD performance

\subsubsection{The Impact of HRT on AD Performance}

Figure 3 shows that Hydraulic Retention Time also has minimal impact on plant performance in terms of COD removal efficiency and methane concentration of the biogas. Trend lines revealed that COD removal efficiencies increased $1 \%$ for every 6.6 hours increase in HRT whilst percentage methane concentration increased $1 \%$ for every 5.3 hours increase in HRT. The poor relationship between performance and HRT is demonstrated by $\mathrm{R}^{2}$ values of 0.0103 and 0.0164 respectively. This is contrary to previous research which indicates a significant link between removal efficiencies and HRT (Rizvi et al., 2013; Ruiz et al., 1998) which is due to the impact HRT (and in turn $\mathrm{V}_{\text {up }}$ ) has on the contact time between wastewater and biomass; the influence it exerts on the creation/formation of gas pockets; its effectiveness of splitting biogas from biomass and solids removal efficiency (Rajakumar et al., 2011). The continued high removal efficiency values and methane concentration signifies the robustness of the process and its ability to cope with high variations of volume (Musse et al., 2016).

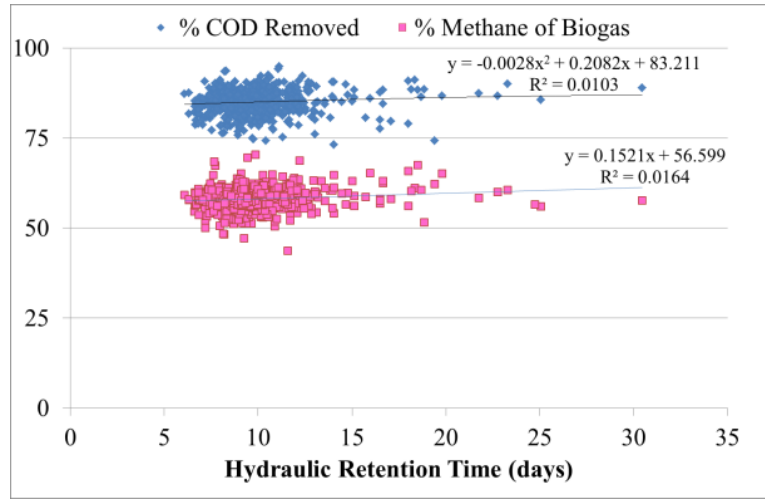

Figure 3. The impact of HRT on \% COD removal and \% Methane in biogas

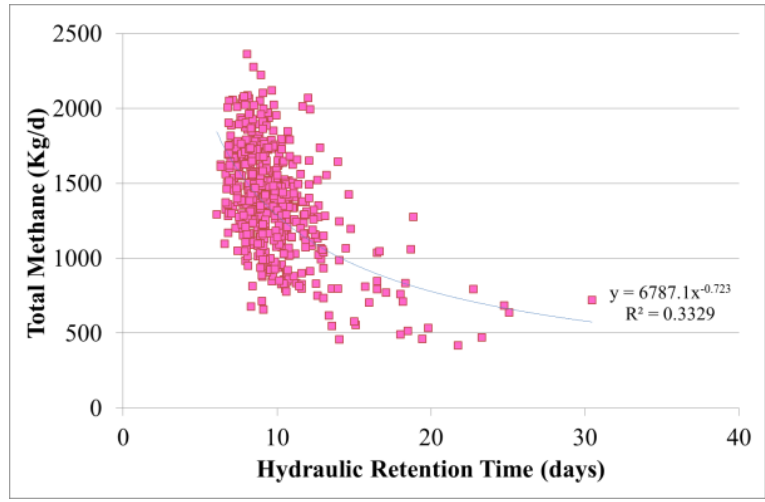

Figure 4. the impact of HRT on total methane production 


\section{Macrothink}

When performance is investigated in terms of hydraulic retention time (Figure 4) it is apparent that total methane production falls off at higher HRTs despite the potential for higher methane concentrations due to longer contact time (Rizvi et al., 2013). It is recognized that after a HRT of 14 days total methane production never exceeds $1500 \mathrm{Kg}$ a day. It is expected that as flow decreases (HRT increases) then so will the OLR. This reduction in feed limits the total amounts of methane that can be created.

\subsubsection{The Impact of Organic Loading Rate on Performance}

Compared to other parameters investigated there is a strong positive trend between OLR and total methane production $\left(\mathrm{R}^{2}=0.6306\right)$ regardless of if the OLR is significantly under the design value of $4 \mathrm{Kg}$ or pushing the maximum design limit of $5.6 \mathrm{KgCOD} / \mathrm{m}^{3} / \mathrm{d}$ (Figure 5 ). The highest total methane being produced on days where OLR $>3 \mathrm{KgCOD} / \mathrm{m}^{3} / \mathrm{d}$ and lowest when OLR is $<3 \mathrm{KgCOD} / \mathrm{m}^{3} / \mathrm{d}$. Despite the increase in COD removal with higher OLR it is worth taking in to account that under higher OLR the plant becomes slightly less efficient with respects to \% methane of the biogas (Figure 6). Like with previous studies (Gao et al., 2007) the OLR had minimal impact on plant efficiency indicating that the plant was robust enough to cope with large variations and thus able to convert the extra COD in to methane.

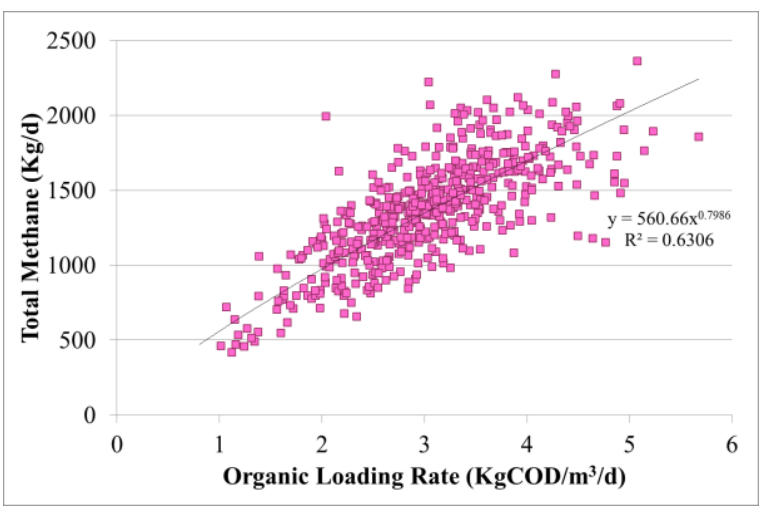

Figure 5. Impact of Organic Loading Rate on Total Methane

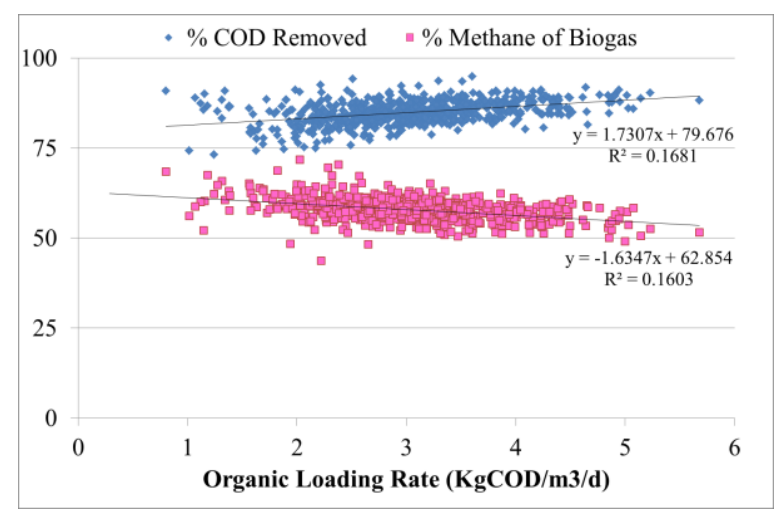

Figure 6. The impact of OLR on \% COD removal and \% Methane in biogas

\section{Conclusion}

In this paper it was demonstrated that the manufacture of malt ingredients produces a high strength effluent $(15,422-49,420 \mathrm{mg} / \mathrm{L} \mathrm{COD})$ with parameters that are within the realms of other organic laden wastewaters that are typically treated by anaerobic digestion, despite there being no comparable characterisation profiles. An Upflow Anaerobic Sludge Blanket under mesophilic conditions has been show to be an effective and robust technology option for the treatment of this type of wastewater resulting in a mean COD removal of $84.94 \%$ and a biogas yield of $3472.14 \mathrm{Nm}^{3} / \mathrm{d}$ (58.08\% methane). Key operating parameters for UASBs typically exert a strong influence on plant performance however in this case operations remained steady despite large variations in HRT (6.07 to 43.04 days) and OLR ( $0.8-5.68 \mathrm{Kg}$ $\mathrm{COD} / \mathrm{m}^{3} /$ day) even when conditions were in excess of the design limit. Due to the robust operational performance of the plant the main factor limiting total methane production was 
shown to be the organic loading rate.

\section{Acknowledgement}

The authors would like to thank Muntons PLC for supporting our AD operations and wider sustainability initiatives with particular thanks to Francis Rowlands, Philip Jacobs, Lawrence Howes and Dr Nigel Davies. Acknowledgement also goes to ADBA and their Chief Executive Charlotte Morton for her continued hard work in promoting developments in the UK AD industry.

\section{References}

ADBA. (2016). Anaerobic Digestion Market Report: December. [Online] Available: http://adbioresources.org/docs/marketreport-dec-2016-40ppa4_v1.pdf (May 15, 2017)

Ammary, B. Y. (2004). Nutrients requirements in biological industrial wastewater treatment. African Journal of Biotechnology, 3(4), 236-238. https://doi.org/10.5897/AJB2004.000-2042

American Public Health Association. (2012). Standard methods for the examination of water and wastewater (Vol. 22). Washington D.C, USA: American Public Health Association.

Bekkering, J., Benders, R. M. J., Moll, H. C., \& Pierie, F. (2016). Spatial and environmental assessment of energy potentials for Anaerobic Digestion production systems applied to the Netherlands. Applied Energy, 176, 233-244. https://doi.org/10.1016/j.apenergy.2016.05.055

Bolzonella, D., Cavinato, C., Fatone, F., Pavan, P., \& Cecchi, F. (2012). High rate mesophilic, thermophilic, and temperature phased anaerobic digestion of waste activated sludge: a pilot scale study. Waste Management, 32(6), 1196-1201.

https://doi.org/10.1016/j.wasman.2012.01.006

Carrere, H., Antonopoulou, G., Affes, R., Passos, F., Battimelli, A., Lyberatos, G., \& Ferrer, I. (2016). Review of feedstock pretreatment strategies for improved anaerobic digestion: from lab-scale research to full-scale application. Bioresource technology, 199, 386-397. https://doi.org/10.1016/j.biortech.2015.09.007

Chávez, P. C., Castilllo, L.R., Dendooven, L., \& Escamilla-Silva, E. M. (2005). Poultry slaughter wastewater treatment with an up-flow anaerobic sludge blanket (UASB) reactor. Bioresource technology, 96 (15), 1730-1736. https://doi.org/10.1016/j.biortech.2004.08.017

Chen, Y., Cheng, J. J., \& Creamer, K. S. (2008). Inhibition of anaerobic digestion process: a review. Bioresource technology, 99(10), 4044-4064.

https://doi.org/10.1016/j.biortech.2007.01.057

Conceição, V., Freire, F. B., \& de Carvalho, K. Q. (2012). Treatment of textile effluent containing indigo blue dye by a UASB reactor coupled with pottery clay adsorption. Acta Scientiarum Technology, 35(1), 53-58. https://doi.org/10.4025/actascitechnol

De Baere, L., \& Mattheeuws, B. (2012). Anaerobic digestion of the organic fraction of municipal solid waste in Europe - Status, experience and prospects. In Thomé-Kozmiensky, K. J., \& Thiel S. (eds.) Waste Management, Vol. 3: Recycling and Recovery (pp. 517-526). 
Neuruppin, Germany: TK Verlag.

Ersahin, M. E., Ozgun, H., Dereli, R. K., \& Ozturk, I. (2011). Anaerobic treatment of industrial effluents: an overview of applications. In Waste Water, Treatment and Reutilization (pp.1-27). https://doi.org/10.5772/16032

Facchin, V., Cavinato, C., Fatone, F., Pavan, P., Cecchi, F., \& Bolzonella, D. (2013). Effect of trace element supplementation on the mesophilic anaerobic digestion of foodwaste in batch trials: the influence of inoculum origin. Biochemical Engineering Journal, 70, 71-77.

https://doi.org/10.1016/j.bej.2012.10.004

Hernández, M., \& Rodríguez, M. (2013). Hydrogen production by anaerobic digestion of pig manure: Effect of operating conditions. Renewable Energy, 53, 187-192.

https://doi.org/10.1016/j.renene.2012.11.024

Huang, J. S., Wu, C. S., \& Chen, C. M. (2005). Microbial activity in a combined UASB-activated sludge reactor system. Chemosphere, 61(7), 1032-1041.

https://doi.org/10.1016/j.chemosphere.2005.03.027

Huang, L., Zhang, B., Gao, B., \& Feng, L. (2009, October). Application of anaerobic granular sludge to treatment of fishmeal industry wastewaters under highly saline conditions. Paper presented at ICEET International Conference on Energy and Environment Technology. https://doi.org/10.1109/iceet.2009.343

Kamali, M., Gameiro, T., Costa, M. E. V., \& Capela, I. (2016). Anaerobic digestion of pulp and paper mill wastes-An overview of the developments and improvement opportunities. Chemical Engineering Journal, 298, 162-182. https://doi.org/10.1016/j.cej.2016.03.119

Koller, T. (2016). ADBA Members Press Release; Muntons project on the shortlist for another energy industry award. [Online] Available:

http://adbioresources.org/news/members-press-release-muntons-project-on-the-shortlist-for-a nother-energy-i (May 18, 2017)

Latif, M. A., Ghufran, R., Wahid, Z. A., \& Ahmad, A. (2011). Integrated application of upflow anaerobic sludge blanket reactor for the treatment of wastewaters. Water research, 45(16), 4683-4699. https://doi.org/10.1016/j.watres.2011.05.049

Lee, C. S. (2006). Biodegradation of oil and grease in upflow anaerobic sludge blanket reactor for palm oil mill effluent treatment (Masters thesis). Retrieved from: http://eprints.utm.my/4063/

Leite, W. R. M., Gottardo, M., Pavan, P., Belli Filho, P., \& Bolzonella, D. (2016). Performance and energy aspects of single and two phase thermophilic anaerobic digestion of waste activated sludge. Renewable Energy, 86, 1324-1331.

https://doi.org/10.1016/j.renene.2015.09.069

Micolucci, F., Gottardo, M., Cavinato, C., Pavan, P., \& Bolzonella, D. (2016). Mesophilic and thermophilic anaerobic digestion of the liquid fraction of pressed biowaste for high energy yields recovery. Waste management, 48, 227-235. 
https://doi.org/10.1016/j.wasman.2015.09.031

Moraes, B. S., Zaiat, M., \& Bonomi, A. (2015). Anaerobic digestion of vinasse from sugarcane ethanol production in Brazil: Challenges and perspectives. Renewable and Sustainable energy reviews, 44, 888-903. https://doi.org/10.1016/j.rser.2015.01.023

Musee, N., Trerise, M. A., \& Lorenzen, L. (2016). Post-treatment of distillery wastewater after UASB using aerobic techniques. South African Journal of Enology and Viticulture, 28(1), 50-55. https://doi.org/10.21548/28-1-1459

Rajakumar, R., Meenambal, T., Banu, J. R., \& Yeom, I. T. (2011). Treatment of poultry slaughterhouse wastewater in upflow anaerobic filter under low upflow velocity. International Journal of Environmental Science \& Technology, 8(1), 149-158.

https://doi.org/10.1007/BF03326204

Rajeshwari, K. V.; Balakrishnan, M.; Kansal, A.; Lata, K., \& Kishore, V. V. N. (2000). State-of-the-art of anaerobic digestion technology for industrial wastewater treatment. Renewable and Sustainable Energy Reviews, 4, 135-156.

https://doi.org/10.1016/S1364-0321(99)00014-3

Rizvi, H., Ahmad, N., Abbas, F., Bukhari, I. H., Yasar, A., Ali, S., Tahira, Y., \& Riaz, M. (2015). Start-up of UASB reactors treating municipal wastewater and effect of temperature/sludge age and hydraulic retention time (HRT) on its performance. Arabian Journal of Chemistry, 8(6), 780-786. https://doi.org/10.1016/j.arabjc.2013.12.016

Satyawali, Y., \& Balakrishnan, M. (2008). Wastewater treatment in molasses-based alcohol distilleries for COD and color removal: a review. Journal of Environmental Management, 86(3), 481-497. https://doi.org/10.1016/j.jenvman.2006.12.024

Singh, L., Wahid, Z. A., Siddiqui, M. F., Ahmad, A., Rahim, M. H. A., \& Sakinah, M. (2013). Application of immobilized upflow anaerobic sludge blanket reactor using Clostridium LS2 for enhanced biohydrogen production and treatment efficiency of palm oil mill effluent. International journal of hydrogen energy, 38(5), 2221-2229.

https://doi.org/10.1016/j.ijhydene.2012.12.004

Surendra, K. C., Takara, D., Jasinski, J., \& Kumar Khanal, S. (2013). Household anaerobic digester for bioenergy production in developing countries: opportunities and challenges. Environmental technology, 34(13-14), 1671-1689.

https://doi.org/10.1080/09593330.2013.824012

Tawfik, A., Sobhey, M., \& Badawy, M. (2008). Treatment of a combined dairy and domestic wastewater in an up-flow anaerobic sludge blanket (UASB) reactor followed by activated sludge. Desalination, 227(1-3), 167-177. https://doi.org/10.1016/j.desal.2007.06.023

Yu, H. Q., Fang, H. H., \& Gu, G. W. (2002). Comparative performance of mesophilic and thermophilic acidogenic upflow reactors. Process Biochemistry, 38(3), 447-454.

https://doi.org/10.1016/S0032-9592(02)00161-9

Wang, W., Wu, B., Pan, S., Yang, K., Hu, Z., \& Yuan, S. (2017). Performance robustness of 


\section{Macrothink}

Environmental Management and Sustainable Development

ISSN 2164-7682

2017, Vol. 6, No. 2

the UASB reactors treating saline phenolic wastewater and analysis of microbial community structure. Journal of Hazardous Materials, 331, 21-27.

https://doi.org/10.1016/j.jhazmat.2017.02.025

\section{Glossary}

AD: Anaerobic Digestion

ADBA: The Anaerobic Digestion and Bioresources Association

$\mathrm{CH}_{4}$ : Methane

COD: Chemical Oxygen Demand

HRT: Hydraulic Retention Time

MI: Malt Ingredients

OLR: Organic Loading Rate

TKN: Total kjeldahl (Organic) Nitrogen

TSS: Total Suspended Solids

UASB: Upflow Anaerobic Sludge Blanket

VFA: Volatile Fatty Acids

$\mathrm{V}_{\text {up: }}$ Upflow Velocity

\section{Copyright Disclaimer}

Copyright for this article is retained by the author(s), with first publication rights granted to the journal.

This is an open-access article distributed under the terms and conditions of the Creative Commons Attribution license (http://creativecommons.org/licenses/by/3.0/). 